\title{
Immunogold Technique Applied to Electron Microscopy of Infectious Pancreatic Necrosis Virus (IPNV)
}

\author{
B. Novoa \\ Instituto de Investigaciones Marinas. CSIC. Eduardo Cabello 6, 36208 Vigo, Spain
}

(Received March 14, 1996)

\begin{abstract}
Immunogold technique in electron microscopy proved to be effective to demonstrate the virusantibody specificity using purified reference strains of infectious pancreatic necrosis virus (IPNV). Although some cross reactions were detected, it was possible to distinguish the major IPNV serotypes (Sp, $\mathrm{Ab}$ and WB) according to the different affinity for the antisera against the three reference strains which were binded to protein A-gold particles. Moreover, tubular structures with a diameter of $60 \mathrm{~nm}$ were detected presenting a high affinity for the gold particles, which suggests a viral origin.
\end{abstract}

Key words : birnavirus, IPNV, immunogold, electron microscopy, serotype

Infectious pancreatic necrosis virus is one of the major causes of mortality in salmonid aquaculture. Although the classification of these viruses is still controversial, three main serotypes can be distinguished: $\mathrm{Sp}$ and $\mathrm{Ab}$ (European serotypes) and West Buxton (WB) which was traditionally an American serotype, but it has been recently isolated from turbot cultured in Europe (Novoa et al., 1993). In the last years, different techniques have been applied to the identification and serology of birnavirus in order to find fast and specific diagnostic methods. Serological techniques using monoclonal antibodies and molecular biological methodology are very reliable and precise methods for viral diagnosis and classification (Caswell-Reno et al., 1986, 1989; Heppell et al., 1992; Melby and Christie, 1994; Novoa et al., 1995). Moreover, localization of the antigen is important to know the exact replication sites of the virus and the interaction with the host. Immunolabelling of viral particles has been extensively used in light microscopy, however, more precise localization can be achieved by the high resolution of the transmission electron microscopy, which even can be improved by immunolabelling with an electron-dense marker such as coloidal gold particles.

In this paper, the use of the immunogold technique in electron microscopy of purified viruses has been investigated in order to discriminate the main serotypes of aquatic birnaviruses.

\section{Materials and Methods}

\section{Viral strains and antisera}

Three strains of IPNV, reference serotypes Sp, Ab and WB, were grown in the chinook salmon cell line (CHSE-214). Cells were cultivated at $18^{\circ} \mathrm{C}$ in Eagle's minimal essential medium (MEM) supplemented with $10 \%$ fetal bovine serum and containing $100 \mathrm{IU}$ penicillin and $100 \mu \mathrm{g}$ streptomycin $/ \mathrm{ml}$. The neutralization antibody titers $\left(\mathrm{ND}_{50}\right)$ of the rabbit polyclonal antisera against the three reference viruses had a value of 10,000 for the homologous strains.

\section{Viral purification}

Ten flasks $\left(150 \mathrm{~cm}^{2}\right)$ with CHSE-214 infected with each viral strain were harvested when cytophatic effect was evident in the monolayers. After centrifugation at $1,000 \times g$ at $4^{\circ} \mathrm{C}$, supernatant was stored at $4{ }^{\circ} \mathrm{C}$ and the precipitate was resuspended in $5 \mathrm{ml}$ of TNE buffer $(0.15 \mathrm{M}$ Tris- $\mathrm{HCl} ; 0.15 \mathrm{M} \mathrm{NaCl} ; 0.001 \mathrm{M}$ EDTA) and sonicated for 30s. (Branson Sonifier 250 ) in order to release the viral particles adsorbed to cellular debries. After this, the suspension was mixed with freon $(1: 1)$ and centrifugated at 10,000 $\times g$. The aqueous phase was collected and the freon extraction was repeated twice. This supernatant was mixed with the stored cell culture supernatant, then polyethylene glycol (PEG) 8,000 (8\%) and $\mathrm{NaCl}$ 
(2.2\%) were added and incubated at $4{ }^{\circ} \mathrm{C}$ overnight. The suspension was centrifuged at $10,000 \times g$ for 80 min and the precipitate was resuspended in $4 \mathrm{ml}$ of TNE. Freon extraction was done twice and virus was concentrated at $1,000,000 \times g$. The precipitate was resuspended in $1 \mathrm{~m} l$ of TNE and was layered in a sucrose gradient $(15-45 \%)$ centrifuging at 34,000 $\times g$. The opalescent interphase was collected and concentrated by centrifugation at $30,000 \times g$ for 90 $\min$.

\section{Immunogold}

Two microliters of the purified virus were applied to a formvard coated grid (400 mesh). After $30 \mathrm{~s}$, grids were washed with phosphate-buffered saline (PBS) for $30 \mathrm{~s}$. Nonspecific binding was blocked with 5\% skim milk in PBS for 10 min. Liquid was blotted out with filter paper and grids were applied to drops of each polyclonal antiserum diluted 1:10 in a skim milk solution in PBS for 10 min. Grids were washed twice with the skim milk solution and were transferred to drops of a solution of gold-A protein (Energy Bean Sciences), with ability to adsorbe immunoglobulins, diluted $1: 10$ in 5\% skim milk in PBS during $30 \mathrm{~min}$. Finally, grids were washed twice in distilled water and stained with uranile acetate for the electron microscope examination. The specificity of the virus-antiserum interaction was determined using an adhesion index (mean number of gold particles binded to each virus divided by the mean number of gold particles binded to the homologous reference strain). A minimum of 15 viruses were counted in each case.

\section{Results and Discussion}

Viral particles presented the typical characteristics of the birnaviruses such as icosahedric morphology, unenveloped and $60 \mathrm{~nm}$ of diameter.

The immunogold technique was very efective to show the virus-antibody specificity (Fig. 1). Although there were cross reactions, higher than those observed in the neutralization test (data not shown), it was possible to distinguish the major IPNV serotypes according to the differences found among the adhesion indexes (Table 1). Antisera against the viral strains $\mathrm{Sp}$ and $\mathrm{Ab}$ resulted to be very specific for the respective viral strains, however, WB antiserum presented cross-reaction with the other viral strains ( 0.75 and 0.78 for $\mathrm{Sp}$ and $\mathrm{Ab}$ respectivelly) although

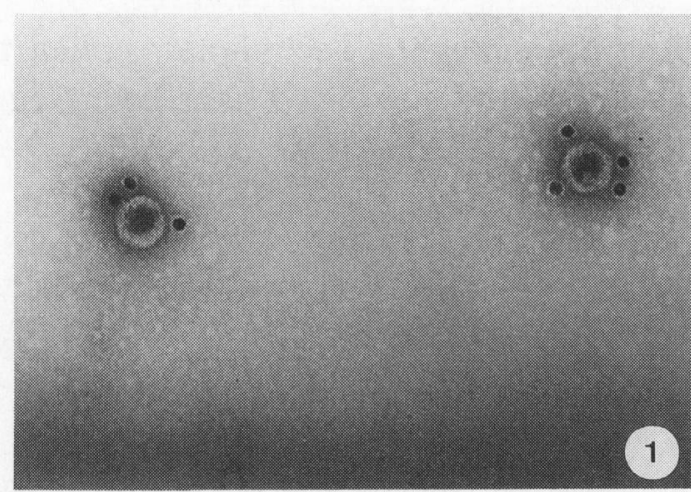

Fig. 1. Immunogold stained birnavirus. Detail of the interaction between the antiserum binded to protein A-gold particles and purified birnavirus.

Table 1. Adhesion index of the different antisera for the three reference strains of aquatic birnavirus (mean number of gold particles binded to the birnavirus divided by the mean number of gold particles binded to the homologous strain)

\begin{tabular}{lccc}
\hline \hline \multirow{2}{*}{ Virus } & \multicolumn{3}{c}{ Antiserum } \\
\cline { 2 - 4 } & $\mathrm{Sp}$ & $\mathrm{Ab}$ & $\mathrm{WB}$ \\
\hline $\mathrm{Sp}$ & $\mathbf{1}$ & 0.44 & 0.75 \\
$\mathrm{Ab}$ & 0.19 & $\mathbf{1}$ & 0.78 \\
$\mathrm{WB}$ & 0.51 & 0.64 & $\mathbf{1}$ \\
\hline
\end{tabular}

always a higher number of gold particles were found binded to the homologous strain than to the other viruses tested.

Although not practical for a routine use, the immunogold technique is useful not only to detect viral antigens but also to distinguish among IPNV serotypes. To our knowledge, this is the first time that this method is applied to the aquatic birnavirus group, with two purposes: identification and serotyping. The identification of viral particles belonging to IPNV was clear, because of the specific interaction with the antiserum. Cross reactions were observed but it was possible to distinguish the reference strains because all of them presented higher affinity for their homologous antiserum. Although other methods were reported for birnavirus serotyping without the requirement of viral purification (Caswell-Reno et al., 1986, 1989; Heppell et al., 1992; Melby and Christie, 1994; Novoa et al., 1995), the present technique has the advantage of the visualization of the virus-antibody interaction. This allowed the identi- 


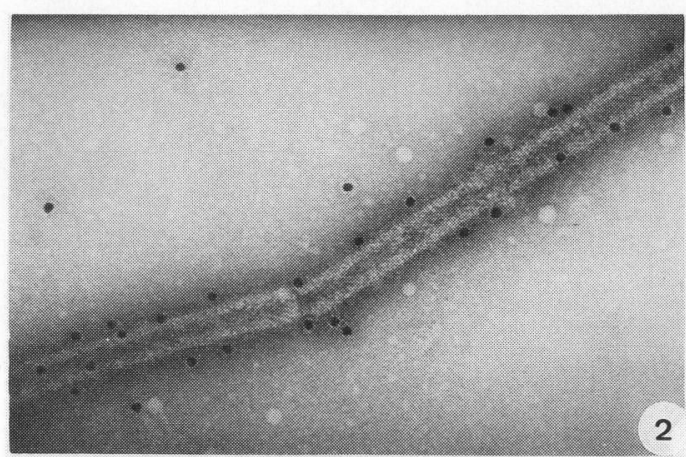

Fig. 2. Tubular structures observed in the purified birnavirus solution stained with immunogold.

fication of some tubular or filamentous structures as being of viral origin when the technique was applied to the purified WB reference strain (Fig. 2). These structures had approximately $60 \mathrm{~nm}$ of diameter and presented a high affinity for the antiserum as it could be visualized by the high number of gold particles binded.

Similar structures were previously reported by Moss and Gravel (1969) in cells infected with IPNV, suggesting that they could be aberrant structures result of assembly errors, as it was detected in other viruses (Hummeler et al., 1967; Watrach, 1962). Comps et al. (1991) published the presence of these tubules in negative stained birnaviruses purified from rotifers (Brachinus plicatilis). However, this is the first time that their viral origin has been definitivelly demonstrated by the high affinity of the antiserum.

Additional studies are being made on transmission electron microscopy of IPNV infected cells since the present study confirms the use of this technology to study viral infections, which could even be improved with the application of monoclonal antibodies.

\section{Acknowledgements}

I thank Dr. F. M. Hetrick (University of Maryland, USA) for his help at the beginning of the experiment. I want also to thank Dr. Antonio Figueras for the critical review of the manuscript. This work was supported by Grant AGF93-0769-C02-02 of the Comisión Interministerial de Ciencia y Tecnología (CICYT).

\section{References}

Caswell-Reno, P., P. W. Reno and B. L. Nicholson (1986): Monoclonal antibodies to infectious pancreatic necrosis virus: Analysis of viral epitopes and comparison of different isolates. J. Gen. Virol., 67, 2193-2205.

Caswell-Reno, P., V. Lipipun, P. W. Reno and B. L. Nicholson (1989): Use of a group-reactive and other monoclonal antibodies in an enzyme immunodot assay for identification and presumptive serotyping of aquatic birnavirus. J. Clinic. Microbiol., 27, 1924-1929.

Comps, M., B. Menu, G. Breuil and J. R. Bonami (1991): Viral infection associated with rotifer mortalities in mass culture. Aquaculture, 93, 1-8.

Heppell, J., L. Berthiaume, E. Tarrab, J. Lecomte and M. Arella (1992): Evidence of genomic variations between infectious pancreatic necrosis virus strains determined by restriction fragments profiles. J. Gen. Virol., 73, 28632870.

Hummeler, K., H. Koprowski and T. J. Wiktor (1967): Structure and development of rabies virus in tissue culture. J. Virol., 1, 152-170.

Melby, H. P. and K. E. Christie (1994): Antigenic analysis of reference strains and norwegian field strains of aquatic birnaviruses by the use of six monoclonal antibodies produced against the infectious pancreatic necrosis virus N1 strain. J. Fish Dis., 17, 409-415.

Moss, H. and M. Bravell (1969): Ultrastructure and sequencial development of infectious pancreatic necrosis virus. J. Virol., 3, 52-58.

Novoa, B., A. E. Toranzo, C. P. Dopazo, J. L. Barja and A. Figueras (1993): Isolation of IPN virus serotype VR-299 from turbot in Europe. Dis. Aquat. Org., 17, 61-65.

Novoa, B., S. Blake, B. L. Nicholson and A. Figueras (1995): Comparison of different procedures for serotyping aquatic birnavirus. Appl. Environ. Microbiol., 61, 2925-2929.

Reed, L. J. and H. Müench (1938): A simple method of estimating fifty per cent end-points. Amer. J. Hyg., 27, 493-497.

Watrach, A. M. (1962): Intranuclear filaments associated with infectious laryngotracheitis virus. Virology, 18, 324-327. 